\title{
EVALUATING KARST RISK AT PROPOSED WINDPOWER PROJECTS
}

William J. Bangsund

Barr Engineering Co., 4700 W. 77 St., Minneapolis, Minnesota 55435 USA, BBangsund@barr.com

Kenneth S. Johnson

Oklahoma Geological Survey, 1321 Greenbriar Dr., Norman, Oklahoma 73072 USA, ksjohnson@ou.edu

\begin{abstract}
Karst can cause a litany of problems for a windpower project, and it is good practice to evaluate karst risk before proceeding with a proposed project. Windpower projects involve widely-spaced structures with small footprints that can cost \$2 million to \$5 million each. Financial viability can prove difficult, so it is important to find useful, inexpensive procedures for evaluating karst risk. The karst-risk-review process we have used can be split into the two categories outlined below.
\end{abstract}

Desktop studies:

- Search for relevant literature

- Review aerial-photo and map, and analyze lineament

- Search for existing well and boring logs

- Survey local experts-landowners, U.S. Geological Survey, state geological survey, cavers, etc.

Field studies:

- Perform site reconnaissance

- Conduct pit tests if bedrock is shallow

- Drill-A normal geotechnical investigation includes one boring per turbine, while karst investigations may include multiple borings per turbine

- Use a downhole camera-May be useful in evaluating extent of voids and convincing clients of risk.

- Conduct geophysical studies

Effectively communicating with developers is critical. They want to know the location of the problem sites and may ask, If there is a cave, what is the chance that a turbine will fail? The geo-professional needs to do the following effectively:
- Explain the short-term (collapse) and long-term (settlement) risks, and mitigation options

- Explain the uncertainty

- Negotiate liability

- Costs of investigation and mitigation

- Get developers to determine how much to spend while understanding how much incremental-risk reduction they will receive

The discussion of karst risk should be ongoing and investigations may proceed on a step-by-step basis as new information is gathered. It's important to determine whether to investigate all sites underlain by a potentially karstic unit or try to rank the sites based on risk before focusing the investigation on those with potentially higher risk. Perturbine karst investigation costs can easily reach $\$ 20,000$ and more, so investigating each site in a 100-turbine development can be a significant commitment. When possible, start karst evaluation early, manage available cash with a stepwise approach, and communicate.

\section{Introduction}

There are no clear-cut approaches for measuring or mitigating karst risk. Unlike flooding risk and seismicity risk, karst risk is not addressed by the Federal Emergency Management Agency or the USGS. Karst may or may not be addressed by local building codes. Karst-risk assessment is further complicated by the remote, sparsely-populated, and undeveloped areas that are often chosen for wind farm sites. In these areas, there is a limited frame of reference for observing subsidence, fewer eyes observing the ground, and, normally, no reason for anyone to care about sinkholes. A sinkhole in downtown Miami gets more attention than a sinkhole in rural Texas.

Karst can lead to a wind turbine tilting and even toppling. Also, subtle differential settlement of even 3 centimeters 
across a 15-meter-wide wind turbine foundation can cause the turbine to be out of tolerance and lead to expensive and time-consuming remedial action. Turbines need to be widely spaced for optimum performance (see Figure 1), so each proposed turbine location may need to be evaluated independently for karst risk. An installed turbine can cost $\$ 2$ million to $\$ 5$ million, so the liability is high.

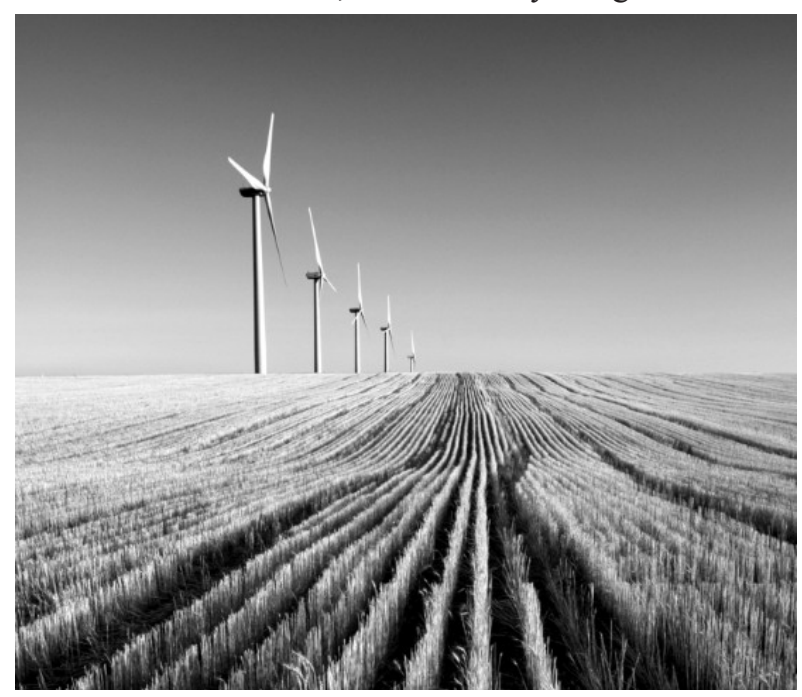

Figure 1. Typical wind farm. Note widely-spaced wind turbines in a remote setting.

Figure 2 is a section of a turbine illustrating the major forces: the wind load, dead load, lateral load, and overturning moment. Turbines have relatively low dead loads but relatively high overturning moments. While there are several types of foundations that can be used, the most common by far is the spread footing shown on Figure 2. The discussion in this paper generally assumes and relates to the use of spread footings. Note that the overturning moment is such a significant factor that ground strength rarely affects the foundation diameter.

Commercial scale windpower projects typically include 10-100 turbines. Employing a common foundation design across the project aids in the economic viability. When a project requires customization of a foundation or foundations to address site-specific conditions, the economics of a project can become untenable.

Figure 3 shows the basic timeline for building a typical wind farm. Once a promising site is identified, several years are spent completing the development phase. When a project enters the development phase, it is still relatively speculative and available funds are limited. As a project moves along the development process- stepping forward toward viability-more funding becomes available. The additional funding affects the karst-evaluation process. Karst evaluation should be stepwise so the early karst evaluation phases can be completed inexpensively, and the more expensive phases are done later when more funding is available.

If possible, the karst professional needs to educate the developer and work with him/her to use funds efficiently. Note that many developers structure projects so that the geotechnical investigation and foundation design are packaged with the construction. In these cases, the issues and implications of karst may come as a surprise, at a point when there is no turning back - the turbines have typically already been purchased. Once in construction, a client has little patience - "just tell me what to do", is the common reaction, until faced with what karst evaluation can cost.

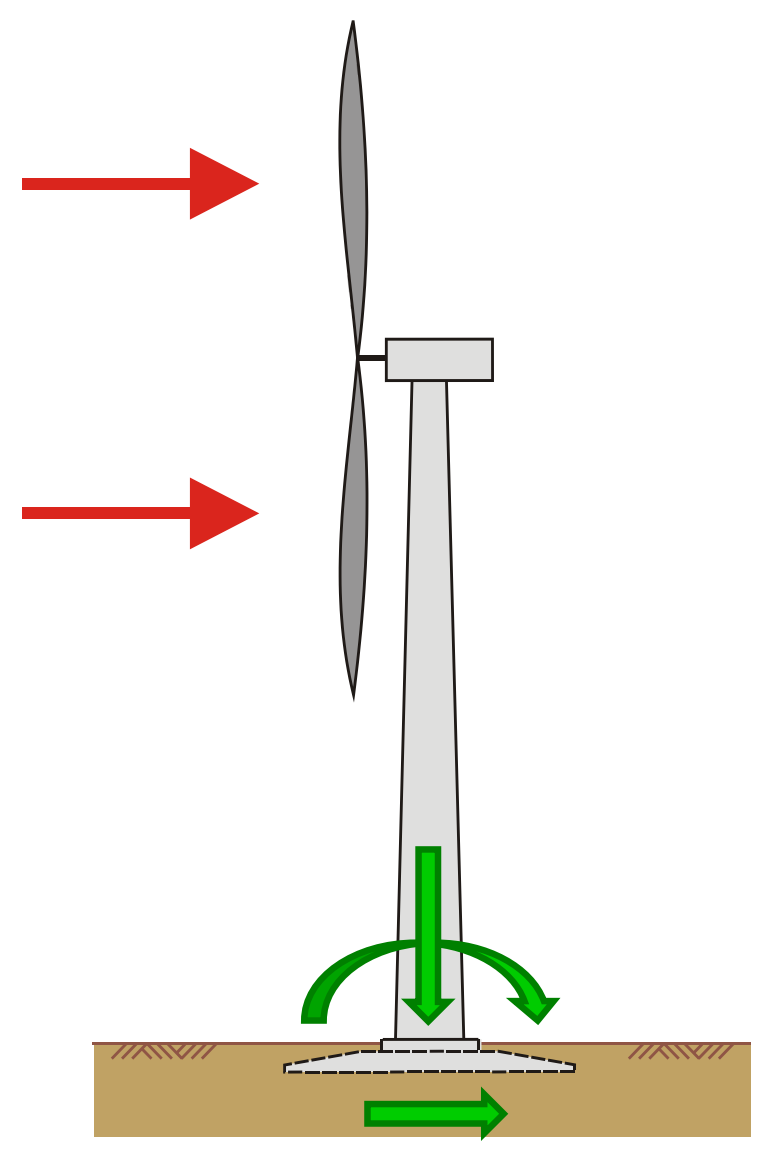

Figure 2. Typical turbine section and major forces. Spread footings are most common. Hub heights 80$100 \mathrm{~m}$ (but can go up to $120 \mathrm{~m}$ ); foundation width 15-22 m; foundation embedment 2-3 m; overturning moment: 35,000 kN*m - 110,000 kN*m; dead load: $1,850 \mathrm{kN}-5,100 \mathrm{kN}$ 


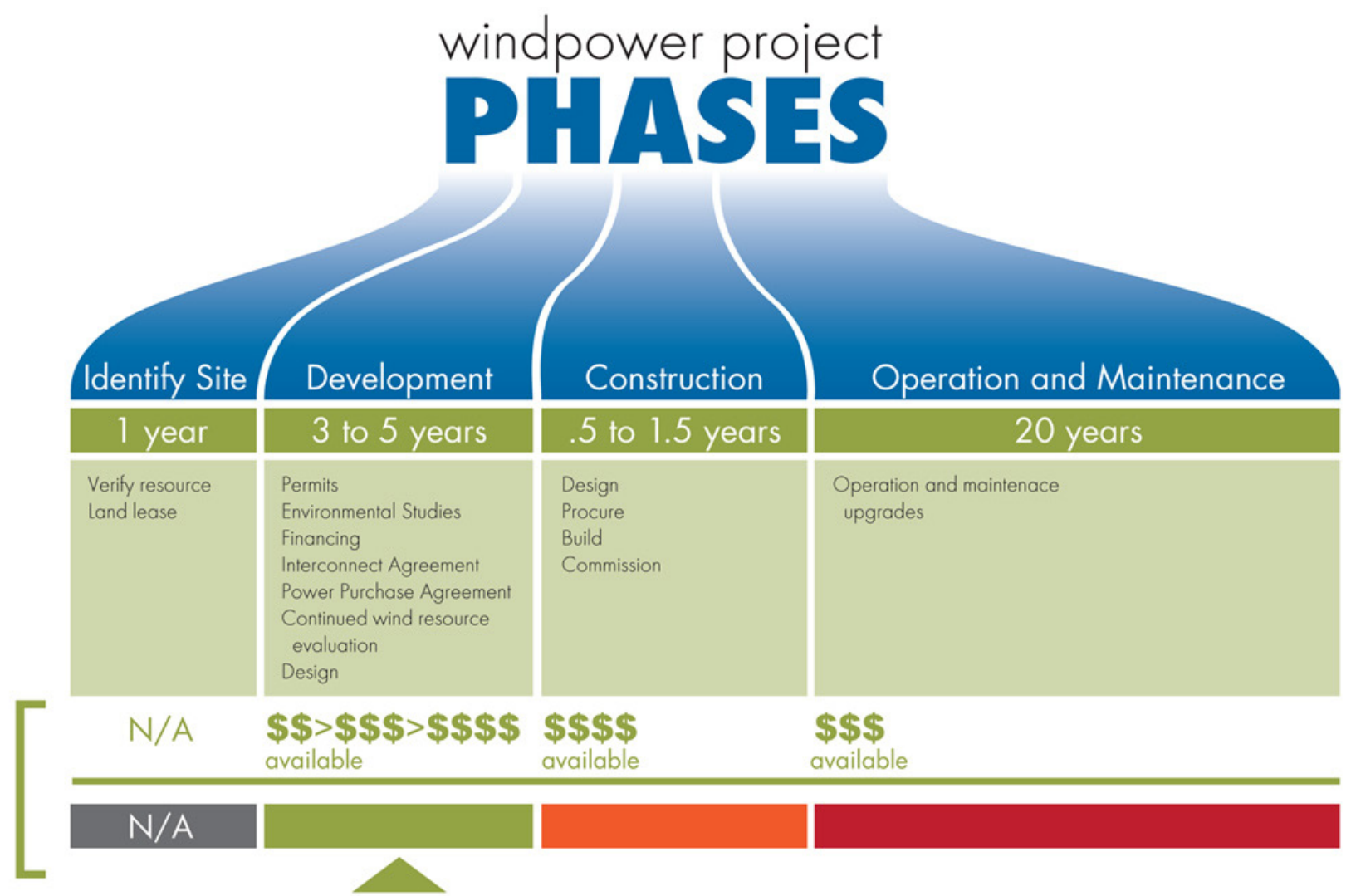

Figure 3. Timeline for developing and operating a typical wind farm.

This paper will address:

- the typical karst investigation methods

- the ways karst risk can be mitigated

- the issues that must be addressed in communicating with the client

- some brief project examples

\section{Investigation Methods}

Keeping a windpower project financially viable can prove difficult, so there is pressure to find useful ways to evaluate karst risk while keeping costs under control.

We have followed a commonly used program (Fischer et al. 1987; Roux, 1987; Tonkin \& Taylor LTD, 2011).

Not every tool is necessary or appropriate for every site:

Desktop studies:

- Literature search

- Aerial-photo and map review, lineament analysis

- Existing well and boring logs search

- Survey of local experts
Field studies:

- Site reconnaissance

- Pit tests

- Geophysics

- Drilling (may include downhole camera and downhole mapping methods)

These methods are listed, approximately, in the order of increasing cost. Because of their cost, drilling and geophysics are usually not undertaken until late in the development process or once the project goes to construction. Hence, available geologic information, especially from geological surveys, is often extremely useful and low-cost.

Literature searches are commonly used on all manner of geologic studies, and there is no need to discuss them further here. One example of something that may be identified at this stage is a stratigraphic correlation to karst occurrence. For example, much of southeastern Minnesota is underlain by carbonate bedrock, but in Mower County the karstification is most developed in the Lithograph City Formation (Green et al., 2002). 
Well logs are a valuable source of information. More and more, states are making water-well information available online. Some examples include:

- Iowa - http://www.igsb.uiowa.edu/about/geosam.htm

- Minnesota - http://www.health.state.mn.us/divs/eh/cwi/

Using remote-sensing techniques is another investigation method with a long history. Maps often show the locations of karstic features, especially springs and sinkholes (Figure 4). USDA Natural Resources Conservation Service soil mapping also includes sinkholes and other karst features for many areas and is available nearly nationwide in GIS format at http://websoilsurvey.nrcs. usda.gov/app/HomePage.htm. Trained and experienced staff can review aerial photographs and topographic maps for apparent karstic features. Today, much of this information is available online, but it is still important to look for historic aerial photographs so the site can be viewed from different perspectives relative to the season and time of day. Modern methods such as interferometric synthetic aperture radar and digital elevation models may be particularly valuable.

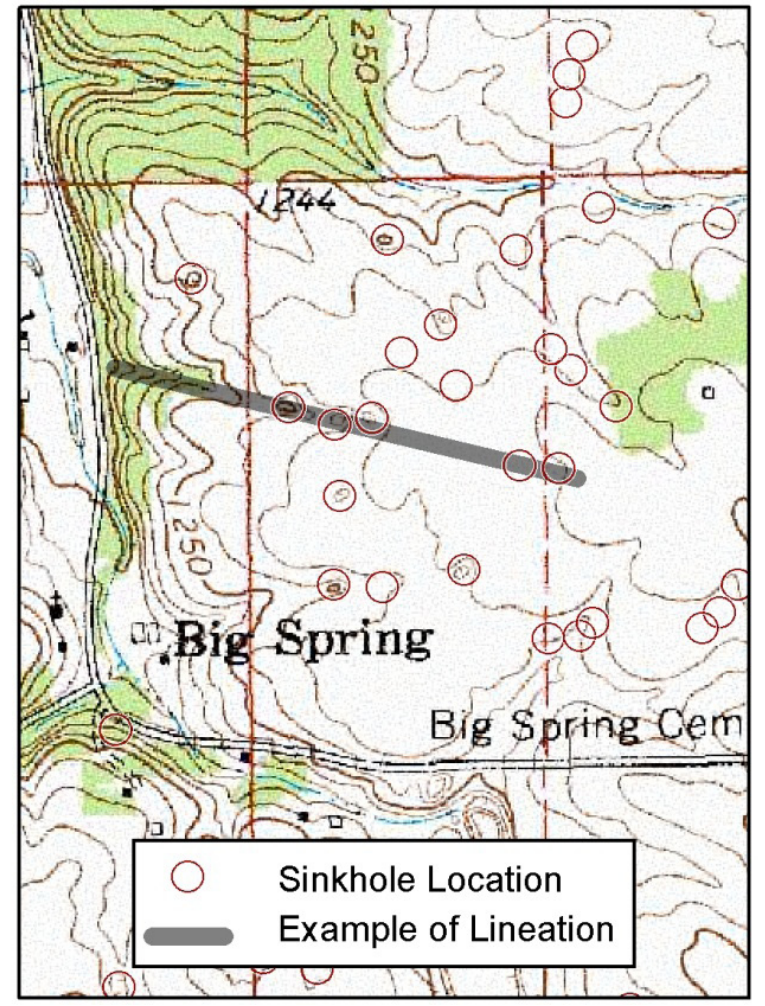

Figure 4. Map of proposed wind farm development area showing mapped karst features and one example of lineation of features.
Karst features tend to form along pre-existing fractures, and epikarst development associated with the deeper karst is commonly why lineaments are expressed on the ground surface (Lattham and Parizek, 1964; WVGES, 1979). While it is hardly definitive, a lineament analysis should be conducted, where appropriate, to identify potential high-risk areas (Figure 5). Some geologic terrains have relatively thick soil covers unrelated to the bedrock that can obscure bedrock lineaments. Lineament analyses have limited or no application in these areas.

There is more than one type of karst, and investigations and mitigation must be appropriate to the local conditions. Local experts are a significant source of information. A good example is co-author Ken Johnson, whose experience in Oklahoma with evaporite karst was invaluable in evaluating evaporite karst risk at the Watonga project in Oklahoma (Johnson et al., 2013). In addition to geological surveys, other geologic experts can be identified during literature searches or found in local colleges or consulting firms. Non-technical sources can include landowners and speleological societies. These non-technical sources can be unreliable and/or

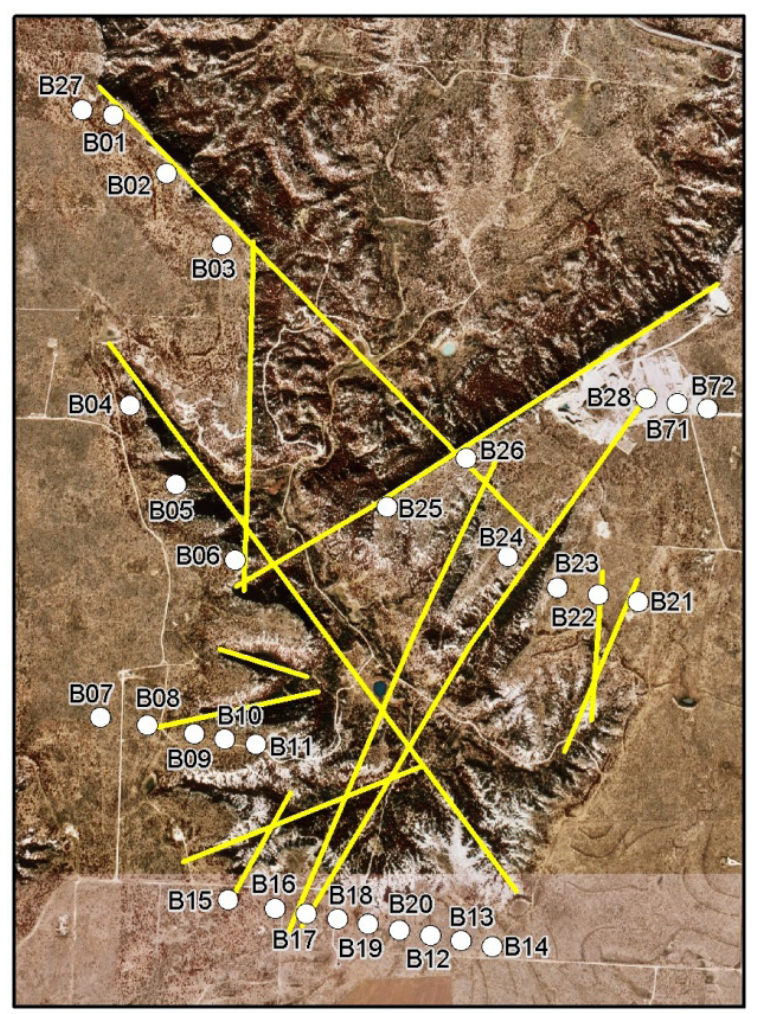

Figure 5. Map of a Scurry County, Texas Wind farm project area showing mapped lineaments. Labeled dots are proposed turbine locations. 
uncooperative because landowners may be concerned about the effect of karst on their land value, and cavers are often reluctant to share private mapping with outsiders or may be philosophically opposed to the project.

Site reconnaissance is important for the general characterization of the area. It may also identify karst features near or at individual turbine sites. Classic geological field techniques and experience with karst are important because so much cost and risk can be based on early findings and decisions. If possible, access to quarries is especially valuable even if outside the immediate project area.

Where bedrock is shallow, test pits can be useful in evaluating the bedrock surface and investigating the nature of depressions to determine whether or not they are related to karst formation.

A normal geotechnical investigation includes one 15- to 25-meter deep boring per turbine. This depth is about equal to the width of the turbine foundation, and the depth is chosen based on the vertical stress induced by the foundation (Das, 2010). Karst investigations may include multiple borings per turbine. The question is, how many are required to assess karst risk? Advanced geotechnical modeling can provide an indication of the size of void verses depth that may be problematic. However, modeling is expensive, especially if conditions vary across the proposed wind farm, requiring multiple models. The cost of drilling multiple borings per turbine quickly increases the cost of investigation.

A downhole camera can be used in conjunction with drilling. This can be especially useful in convincing the client that there is a risk. Although not used by these authors, laser scanning and 3D mapping may also prove useful.

The use of geophysics in karst evaluations is well studied and reported, and it is regularly addressed at karst conferences (Beck and Wilson, 1987; Beck and Stephenson, 1997; Beck, 2003), including this one. No single technique works everywhere. Ground penetrating radar is one of the most widely-available geophysical tools, but it rarely attains a useful depth of penetration; the base of a turbine foundation is typically 2 to $3 \mathrm{~m}$ below grade. In fact, most geophysical methods lack the fine resolution required to characterize risk. A relatively small void occurring $4 \mathrm{~m}$ below grade could be difficult to image, yet it would pose significant risk to a turbine. In many karst areas, soil piping presents a major risk for the creation of a void that doesn't currently exist. At its best, geophysics identifies anomalies. The nature of the anomalies must then be determined through drilling.

Risk characterization has a number of questions:

- Is the subgrade potentially subject to karst formation?

- Are there any known karst features in the region?

- Are there karst features in the project area?

- Are there karst features at the proposed turbine sites?

The results at each stage of evaluation are used to determine if more investigation is required and, if so, the scope of the next phase.

One of the most difficult situations is where there is shallow carbonate or evaporite bedrock and no evidence of karst from the desktop phase or reconnaissance. The lack of evidence does not mean there is no risk. The question then is, how much investigation is required? Lineament analysis has been used to identify areas with higher potential risk. Then, intense investigation can be completed in these areas. If no subsurface voids are found, it may be acceptable to forego further karst investigation in other areas.

\section{Risk mitigation}

Once karst risk has been confirmed and characterized, mitigation must be applied. More than one method of mitigation may be used on a windpower project. There are several ways of mitigating karst risk:

- Move the turbines at risk. It may be possible to determine low-risk and high-risk areas. The high-risk sites can be abandoned. Developers have learned to include alternative locations early in the process for this type of outcome. Depending on the number of sites that are eliminated and the number of alternate sites, the cost may range from practically nothing to the loss of the investment and revenue related to the net lost sites.

- Conduct detailed investigation. Some developments may have very limited constraints on where turbines can be placed, and distant lowrisk alternative locations may not be available. A developer can then decide to do more intensive 
investigation of a proposed turbine location to see if moving the turbine a short distance can reduce risk. This method of mitigation can add tens of thousands of dollars and may not be successful.

- Provide thick soil cover to mitigate the risk of subsidence. In some areas, thick soil unrelated to the bedrock (glacial till, wind-blown deposits) may provide an effective bridge over bedrock karst features, and soil thickness may be preliminarily determined based on existing mapping and drilling logs. Eventually, each proposed turbine site should be drilled to determine actual soil thickness.

However, the question of how much soil is enough needs to be answered. There may be precedents.

Goa et al. (2002) found that most surface karst expressions in Minnesota occur where there is less than $15 \mathrm{~m}$ of glacial cover. The Minnesota Geological Survey's Mower County geological atlas (Green et al., 2002) concluded that evidence of karst features was not found for areas with more than $23 \mathrm{~m}$ of glacial cover. For the proposed Watonga project in Oklahoma, the conclusion was similar for terrace and dune deposits (Johnson et al., 2013). In the end, the geologist and the developer need to come to their own conclusion. Since a typical geotechnical investigation for foundation design includes borings at each proposed turbine site, this mitigation method is effectively cost-free.

- Use construction methods. Most turbine spread foundations are relatively shallow $(\sim 2$ to $3 \mathrm{~m}$ below grade at the base). Alternatively, the foundation can be placed on piles that are supported on rock below the karst zone. This may require additional investigation of the bedrock for the design of a pile foundation. Another option is to grout the underlying voids full to eliminate the potential for collapse. One advantage with grouting is that you can complete the detailed investigation to identify voids at the same time as the mitigation is being completed. Another possible construction method not encountered by these authors is to construct a foundation that bridges the risk zone. While a typical spread foundation is likely capable of bridging a small gap, the normal design process does not evaluate that possibility. Such a design consideration would need to be addressed on a case-by-case basis. Constructed mitigation adds hundreds of thousands of dollars to the cost of each turbine. Note that implementing constructed mitigation often means that detailed karst characterization is no longer required.
- Don't build the project. Developers typically have a pipeline of projects in development, so the best approach may be to move on to the next one. This means losing the investment to that point, so this is not done lightly. There is often great pressure to move forward despite the evidence of karst.

As noted previously, the earlier that karst risk can be identified and evaluated, the earlier the developer can factor the costs into the overall project budget. If karst is not identified until the construction phase, it is likely that the project cannot be stopped, and it may be very difficult for the project to ultimately be profitable.

\section{Risk communication}

The cost of failure of a single turbine can range from hundreds of thousands of dollars (slight but unacceptable differential settlement) to millions of dollars (extreme tilt to catastrophic collapse). It is therefore important to communicate the cost implications to the client as early in the project as possible. Part of dealing with the risk of karst is the apportionment of risk amongst the developer, the contractor, and the consultant/designer. Karst risk and risk apportionment is a very important conversation.

The financial commitment to the consultant/designer is often not significant enough to expect him/her to follow through with the level of investigation needed to completely characterize the risk or carry all the liability for a failure. A consultant/designer earns about \$5,000 per turbine, which does not offset the potential for a lost \$5 million turbine-especially when that risk is multiplied by tens or hundreds of turbines. Therefore, it is important to educate the client about karst and karst risk to the extent that the client can carry the bulk of the risk and can make informed decisions regarding the degree of risk and how extensive the risk characterization will be.

Effectively communicating with developers is critical. They want to know the exact location of the problem sites and may ask, "if there is a cave, what is the chance that a turbine will fail?" The developers typically don't understand karst and that, in many cases, the issue is cover collapse or soil piping, not cave collapse. It is also important to communicate the inherent uncertainty of karst risk and the cost of reducing the uncertainty. 
The consultant/designer has several options regarding liability:

- Ignore the issue. This is clearly unacceptable.

- Add a disclaimer. The disclaimer will state that it is impossible to completely know what is underground. This is a typical practice.

- Keep the investigation and evaluation of karst out of scope. In other words, pass the buck.

- Educate the client. Have the client make the major decisions and carry the majority of the risk. This is often resisted since it increases the client's workload and risk.

\section{Project Examples}

Table 1 summarizes the extent of investigation on projects where karst risk was evaluated mainly by the senior author. Following are some brief descriptions of a few of these sites.

\section{North Central lowa}

There are sinkholes near, but not in, the project area. Drilling indicated that the bedrock is dolomitie (as opposed to limestone), with which karst development is linked in this region. Further, the drilling showed that sufficient soil cover exists over most of the site to mitigate risk (Figure 6) and did not find significant indications of karst development. After close consultation with the developer, this project was built.

Table 1. Project Summaries. $N A=$ Project did not advance

\begin{tabular}{|c|c|c|c|c|c|c|c|c|c|}
\hline $\begin{array}{l}\text { Site } \\
\text { Location }\end{array}$ & $\begin{array}{l}\text { No. of } \\
\text { turbines }\end{array}$ & Built? & $\begin{array}{l}\text { Lit } \\
\text { Search }\end{array}$ & $\begin{array}{l}\text { Remote } \\
\text { Sensing/ } \\
\text { Lineament }\end{array}$ & Experts & Recon & Drill & $\begin{array}{l}\text { Geophys- } \\
\text { ics }\end{array}$ & Comment \\
\hline Arizona 1 & 62 & No & Yes & Yes & Yes & NA & $\mathrm{NA}$ & NA & $\begin{array}{l}\text { Project has not } \\
\text { progressed past } \\
\text { desk top phase }\end{array}$ \\
\hline Arizona 2 & 62 & Yes & Yes & Yes & Yes & Yes & Yes & Yes & $\begin{array}{l}\text { Developed area } \\
\text { was reduced }\end{array}$ \\
\hline Iowa & 79 & Yes & Yes & NA & Yes & Yes & Yes & Yes & Glacial cover \\
\hline Kansas & 100 & Yes & Yes & Yes & Yes & Yes & Yes & Yes & \\
\hline Minnesota & $\sim 140$ & No & Yes & Yes & Yes & Yes & NA & Yes & $\begin{array}{l}\text { Unbuilt as of } \\
\text { spring } 2012\end{array}$ \\
\hline New York & $\sim 90$ & No & Yes & Yes & Yes & Yes & NA & Yes & $\begin{array}{l}\text { Karst ID'd } \\
\text { early. Develop- } \\
\text { er kept looking } \\
\text { for a different } \\
\text { answer }\end{array}$ \\
\hline Ohio & 175 & Yes & Yes & No & Yes & Yes & Yes & Yes & Glacial cover \\
\hline Oklahoma 1 & 129 & Yes & Yes & No & No & No & Yes & Yes & $\begin{array}{l}\text { Due to } \\
\text { constraints } \\
\text { and schedule, } \\
\text { investigation } \\
\text { jumped right to } \\
\text { field work }\end{array}$ \\
\hline Oklahoma 2 & $\sim 90$ & No & Yes & No & Yes & Yes & NA & NA & $\begin{array}{l}\text { Dune cover } \\
\text { Watonga }\end{array}$ \\
\hline Pennsylvania & 24 & Yes & Yes & NA & Yes & Yes & Yes & Yes & $\begin{array}{l}\text { Expensive } \\
\text { mitigation }\end{array}$ \\
\hline Texas 1 & 160 & Yes & Yes & Yes & Yes & Yes & Yes & Yes & $\begin{array}{l}\text { Field investiga- } \\
\text { tion was limited } \\
\text { based on linea- } \\
\text { ment analysis }\end{array}$ \\
\hline Texas 2 & 242 & Yes & Yes & Yes & No & Yes & No & Yes & \\
\hline Texas 3 & 260 & Yes & Yes & Yes & Yes & & No & Yes & \\
\hline Texas 4 & $28^{\circ}$ & Yes & Yes & Yes & Yes & Yes & Yes & Yes & $\begin{array}{l}\text { 3-D geotechni- } \\
\text { cal modeling }\end{array}$ \\
\hline
\end{tabular}




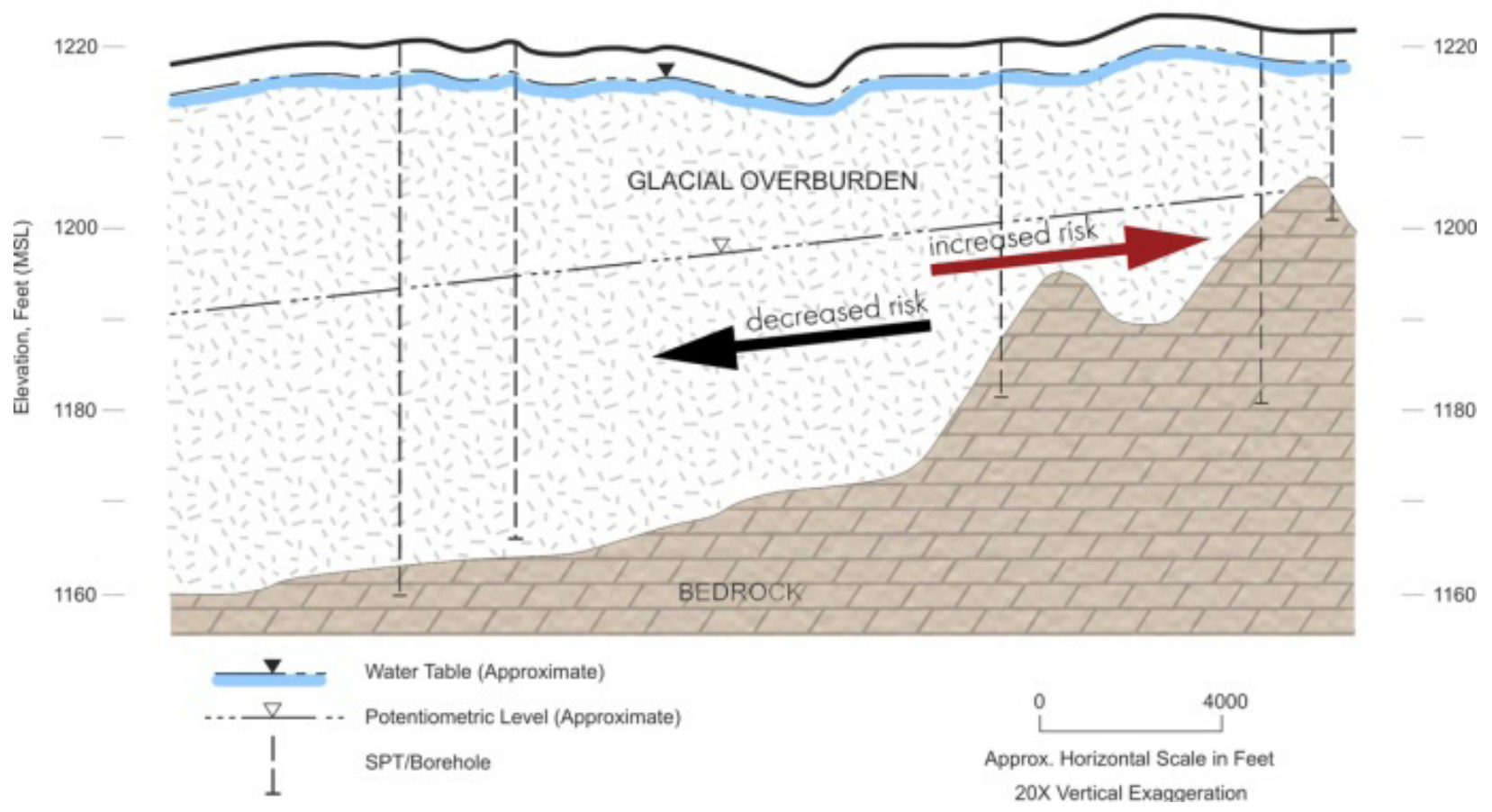

Figure 6. Cross section of wind project in North Central lowa showing depth to bedrock. Thicker soil=less risk.

\section{Southwest Pennsylvania}

Literature review indicated, and site reconnaissance confirmed, that karst features were present in the area. Karst was associated with particular stratigraphic units, so areas of relative risk could be mapped (Figure 7). However, the site had other restrictions on where development could take place, and those limitations took precedence over karst risk. The developer took this project into construction before any subsurface investigation was completed. Once drilling began, numerous subsurface voids were found beneath most of the proposed turbine locations. In some places, multi-channel analysis of surface-wave geophysics was used to see if there were adjacent locations with reduced risk (Figure $8)$. However, the geophysics could not resolve fineenough detail, so multiple drill holes were completed at turbine locations that were at risk. Although not budgeted for, the developer ended up installing deep pile foundations at some sites and grouting voids in others, at great expense.

\section{South Central Minnesota}

The client was a contractor bidding on constructing the project. This is one of the most heavily karstified

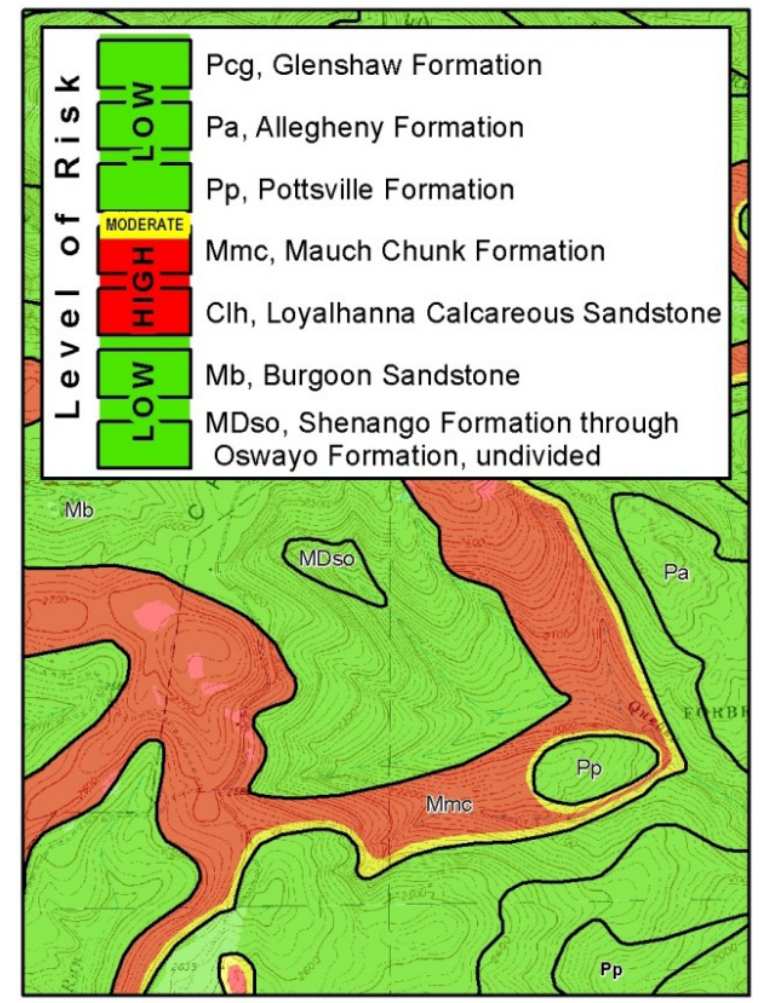

Figure 7. Map showing relative risk for a wind farm in southwest Pennsylvania. 


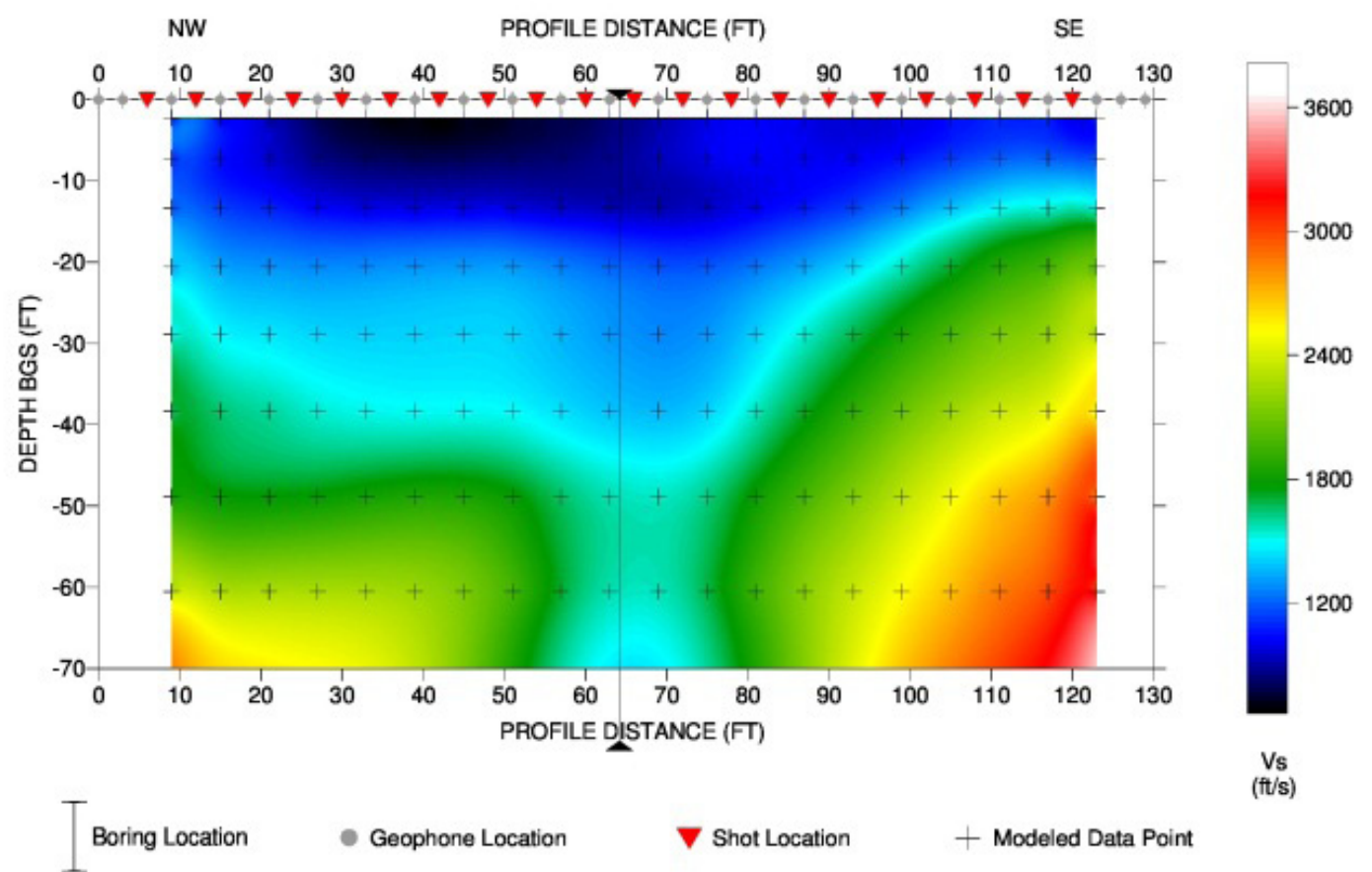

Figure 8. Cross section of shear wave velocity showing a sinkhole underlying a proposed wind turbine site in southwest Pennsylvania. Boring blow count decreased with depth.

areas of Minnesota (Figure 4). The contractor was advised to decline to bid on the project. To date, the project has not been built, although the developer continued to try to bring it to fruition for several years.

\section{Northwest Oklahoma}

Investigations in Blaine County, in northwestern Oklahoma, evaluated potential problems that gypsum karst may pose for the proposed Watonga Windpower Project. Gypsum beds of the Permian Blaine Formation underlie all parts of the Project Area, at depths ranging from 10 to $45 \mathrm{~m}$ below ground level. The Blaine is overlain by the Permian Dog Creek Shale and by unconsolidated Quaternary sands, clays, and gravels that may obscure karst features. Field studies, aerial-photo analysis, and a literature study showed that there is no direct evidence of gypsum karst in the project area. Placing wind turbines at sites where there was sufficient cover overlying the gypsum beds was appropriate risk mitigation: where gypsum is $25 \mathrm{~m}$ below ground level or deeper, the risk related to gypsum karst is low, and where gypsum beds are less than $25 \mathrm{~m}$ deep, risk was medium to high. A map (Figure 9) was prepared showing areas of low, medium, and high risk related to gypsum karst.

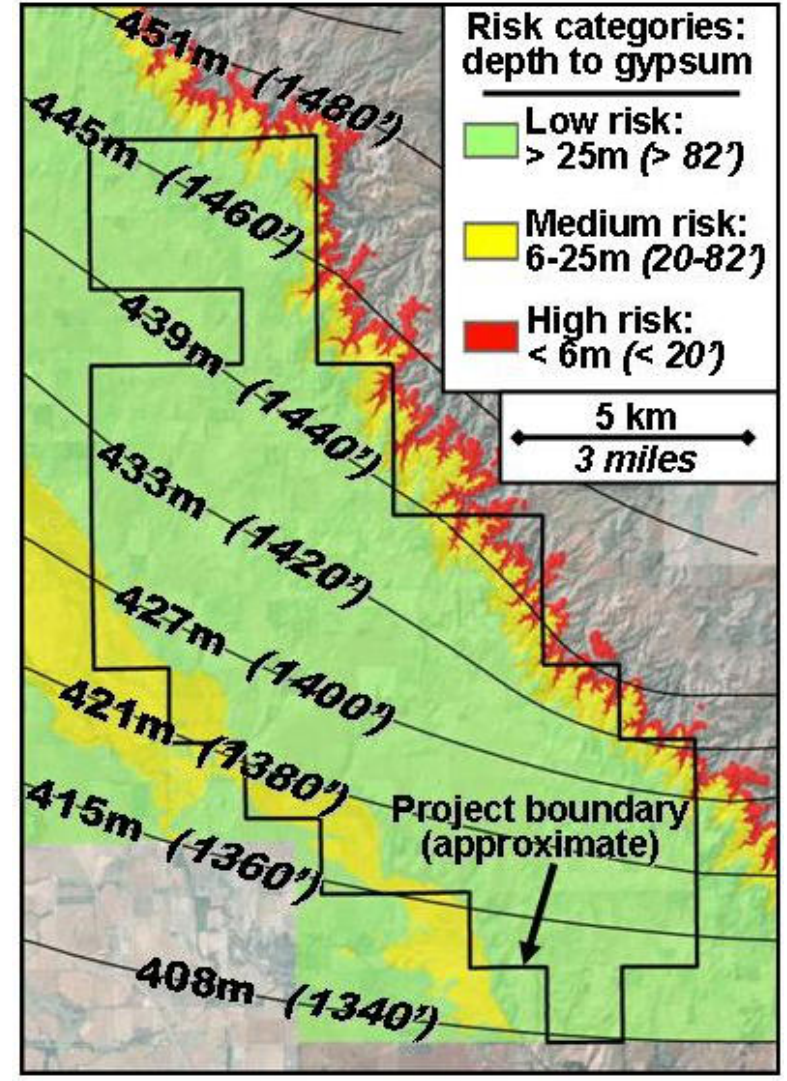

Figure 9. Risk categories at Watonga Windpower Project, based upon depth to the Shimer Gypsum at top of the Blaine Formation (Johnson et al., 2013) 


\section{Conclusions}

Karst can lead to dramatic tilting and even toppling of a wind turbine. Subtle differential settlement of even 3 centimeters across a 15-meter-wide wind turbine foundation can cause the turbine to be out of tolerance, requiring remedial action. There are many tools available for evaluating karst risk at windpower developments, including low-cost desktop methods and field methods with widely ranging costs from reconnaissance to intensive drilling. The right tools at any given phase of a windpower development will be based on the site conditions, the funds available, and the riskmanagement discussions with the client.

\section{References}

Beck BF, editor. 2003. Sinkholes and the Engineering and Environmental Impacts of Karst. Geotechnical Special Publication No. 122. Proceedings of the 9th Multidisciplinary Conference, Huntsville, Alabama. ASCE.

Beck BF, Wilson WL, editors. 1987. Karst hydrogeology: Engineering and Environmental Applications. Proceedings of the 2nd Multidisciplinary Conference on Sinkholes and the Environmental Impacts of Karst. Orlando, Florida. Rotterdam (Netherlands): A.A. Balkema.

Beck BF, Stephenson JB, editors. 1997. The Engineering Geology and Hydrogeology of Karst Terranes. Proceedings of the 6th Multidisciplinary Conference on Sinkholes and the Engineering and Environmental Impacts of Karst. Springfield, Missouri. Rotterdam (Netherlands): A.A. Balkema.

Das, BM. 2010. Principles of geotechnical engineering. 10th Edition. CENGAGE Learning. p. 285.

Fischer JA, Greene RW, Ottoson TS, Graham TC. 1987. Planning \& design consideration in karst terrain. In: Beck BF, Wilson WL, editors. Karst Hydrogeology: Engineering and Environmental Applications. Proceedings of the 2nd Multidisciplinary Conference on Sinkholes and the Environmental Impacts of Karst. Orlando, Florida. Rotterdam (Netherlands): A.A. Balkema. 323-330.

Green JA, Alexander EC Jr, Marken WJ, Alexander SC. 2002. Geologic atlas of Mower County. Minnesota Department of Natural Resources. County Atlas Series, Atlas C-11, Part B, Plate 10 of 10.

Johnson KS, Bangsund WJ, Hines NA. 2013. Gypsum karst and potential problems in siting wind turbines in Blaine County, Oklahoma. NCKRI Conference Proceedings.

Lattham LH, Parizek RR. 1964. Relationship between fracture trace and occurrence of groundwater in carbonate rocks. Journal of Hydrology 2: 73-91.
Roux P. 1987. The engineering-geological evaluation of sites proposed for development in the dolomite karst regions of southern Africa. In: Beck BF, Wilson WL, editors. Karst Hydrogeology: Engineering and Environmental Applications. Proceedings of the 2nd Multidisciplinary Conference on Sinkholes and the Environmental Impacts of Karst. Orlando, Florida. Rotterdam (Netherlands): A.A. Balkema. p. 331-336.

Tonkin \& Taylor, Ltd. 2011. Puketoi Wind Farm Geotechnical Investigation and Design Report. Prepared for Mighty River Power Ltd.

West Virginia Geological and Economic Survey. 1979. Karst subsidence and liner features, Greenbrier and Monroe Counties, West Virginia. Map ECS 17. 